\title{
THE GENUS CYRTOPOGON (DIPTERA; ASILIDÆ) ${ }^{1}$
}

\author{
By A. L. Melander.
}

In the elaboration of Osten Sacken's table of Cyrtopogon given in Back's 1909 study of Robber-flies thirty species are included. This genus is particularly well represented in the Pacific States and several new forms have been discovered by western collectors since the publication of Back's review. Accordingly the following indentification table is appropriate to bring to date our knowledge of this group of especially interesting flies. References are given in the table to those species described since Back's paper was published.

Many of the species of Cyrtopogon exhibit sex dimorphism. This is particularly the case with those species having red antennæ. At times the males and females look quite unlike. The males present easy recognition characters in their elaborate and brilliant sex attire, but sometimes the more modest appearing females of several species resemble each other so closely as to be differentiated with difficulty.

The characters used in the table are for the most part reasonably constant. There is some individual variation in the color of the legs and of the hairs of face, hypopleuræ, scutellum, abdomen and legs, and in the extent of interruption of the abdominal fasciæ. Where such variations have been sufficient to cause doubt in interpreting the table, cross-references have been introduced for more accurate guidance. Types of the new species are in the writer's collection.

\section{Key to the Species of Cyrtopogon.}

1. Scutellum convex, generally long-pilose, usually shining or with touch of pollen at base, rarely pollinose among the species with long arista. . . . . . . . . . . . . . . . . 2 . Scutellum flattened and uniformly and quite densely pollinose; antennæ black. . . . . . . . . . . . 32 . 
2. Third antennal joint red; mystax largely white or yellow;. (if halteres are blackish and face has white hairs, see longimanus; if large species with base of abdomen densely pilose, see dasyllis) . . . . . . . . . . . . . . . . . . . . . . . 3. Third antennal joint black. . . . . . . . . . . . . . 11.

3. Tibiæ and tarsi more or less reddish. . . . . . . . . . . 4. Legs black; claws white with black tip. . . . . . . . . 10.

4. Pile of scutellum and hypopleuræ white; apex of femora reddish; mystax mostly white; pile of tibiæ and pleuræ very long. (Can., N. H., Ct., N. Y., Mass., Va., N. C. marginalis Lw.

Pile of scutellum black; of hypopleuræ more or less black; femora black; western species. . . . . . . . . . . 5 .

5. Front tibiæ and tarsi of male silvery pilose on posterior side; wings hyaline.

Legs not silvery, but sometimes with yellowish white hairs fringing tarsi; pile of male abdomen more or less tufted; wings with light clouding about veins, anterior crossvein near base of discal cell. . . . . . . . . . . . . . . . 7 .

6. Male: front tibiæ with fine white silky pile on outer side, becoming longer and denser apically; front tarsi with silvery hairs on anterior side of joints $2-5$ in addition to the silvery hairs on posterior side; abdominal segmeits 1,2 with pale yellow pile,longer on sides,remaining segments with very short hair, yellowish on 3 , black on rest, segments 2-5 white-fasciate, interrupted on 4,5 .

pulcher Back

Male: front tibiæ with moderately long silvery pile posteriorly, short yellow pile anteriorly; front tarsi with yellow hairs on anterior side of first two joints; abdomen with reddish yellow pile forming dense apical bands on segments 1-4, segments 2-4 silvery fasciate. (Alta.) (Can. Ent. liv. 278, 1922) . . . . . . albitarsis Curran.

7. Pile of abdomen yellow or fulvous at least on first segment, tip of male abdomen blue-black, segments 2-4 with complete fasciæ, sometimes hidden by dense pile in male; basal half of claws reddish. . . . . . . . . . . . . 8 . 
Male abdomen with lateral tufts of black not fulvous hair, female with less tufted black and white pile, abdomen with interrupted white pollinose fasciæ; claws black, front tarsi of male very long. (Or.) (Proc.Cal. Acad. Sc., 1919, 233) . . . . . . . . . . .perspicax Cole

8. Male abdomen with black tuft on sides of second segment, a dorsal pollinose vitta on segments $2-5$, female abdomen with lateral pile pale yellow and almost entirely confined to basal two segments; male front tibiæ with white pubescence toward tip, tarsi yellow with brush of yellowish-white hairs along entire outer face and with black bristles inside, tarsi of female reddish; central hairs of face mixed black and white. (Wash.) . . glarealis, n. sp. Male abdomen with dense fulvous pile arranged in tufted bands across segments 2-4, no dorsal vitta, yellow pile of female abdomen continuing on third segment. . . . 9 .

9. Segments 5-7 of male abdomen with dense tufts of short black velvet pile; front tibiæ and tarsi without brush on posterior side, bristles black, some white pile on extensor face of male tarsus; female with tarsal joints tipped with black and with center hairs of face white. (Cal., Wash.) . . . . . . . . . . . aurifex O. S.

Segments 5-7 of male abdomen not tufted; posterior edge of front tibiæ and tarsi of male with uniform brush of white hairs containing white bristles; female with yellowish tarsi and with central hairs of face yellow. (Or., Id.) (Proc. Cal. Acad. Sc. 1919, 230.) . . . . . auratus Cole

10. Thorax white-gray pollinose, markings nearly obsolete; wings hyaline; face and front heavily coated with cinereous pollen. Male unknown. (Cal.) . . . . .cretaceus O. S. Thorax of male black, of female brown and gray; wings of male black, of female subfuscous; male front tarsi very long, silvery on extensor side, hind tibiæ and tarsi silvery pilose. (Cal., Or., Wash.) . . . . . . . princeps O. S.

11. Style nearly as long as third joint of antennæ; wings with distinct dark spots on furcations and crossveins; scutellum often dusted. 
Style evidently shorter than third joint of antennæ. . . 15 .

12. Thorax compressed gibbous, the undivided median stripe bearing a strong mane of long black pile and setiform hairs; scutellum margined with long black setæ; costal and marginal cells hyaline; halteres black. (Wash.) maculosis Coq.

Thorax convex as usual, with erect black pile but no mane; scutellar bristles less developed; middle dorsal stripe geminate. . . . . . . . . . . . . . . . . . . 13 .

13. Costa fringed with uniform close hairs; pile of face tipped with white; halteres black. (Cal., Or., Wash., B. C.) nebulo $\mathrm{O}$. S.

Costa with only microscopic hair; white tips of facial hairs less evident; costal and marginal cells brown apically. 14 .

14. Halteres black; a single spot in first basal cell at origin of third vein. (Id., Wash.) . . . . . punctipennis, n. sp.

Halteres yellowish; first basal cell with two blackish spots near middle. (Wash., Or.) . . . . . varipennis Coq.

15. Abdomen with dense erect pile forming a bright yellow band across middle part, and black at tip. 16 .

Abdomen not densely clothed but sometimes with lateral or parted tufts of pile in male. . . . . . . . . . . . 18 .

16. Style short and thick, almost square; wings hyaline; anterior crossvein near base of discal cell; anterior tibiæ and front tarsi with dense white pile on extensor face; yellow pile of abdomen confined to basal three segments. (Wash.) semitarius. n. sp.

Style longer than wide; anterior crossvein near middle of discal cell; hairs of legs black aside from the fulvous recumbent pubescence on inside of front tibiæ.

17. Wings of male with large black sharply limited spot; all hairs of head black; yellow hairs of abdomen confined to segments 2-4 (Col., Id.) . . . . . . . . . dasyllis Will.

Wings with dark spot more suffused; hairs of face and beard yellow; yellow hairs of abdomen extending on fifth segment. (Wash., Or., Id., Cal., N. Y.) . . dasylloides Will. 
18. At least hind tibiæ in part reddish, usually anterior pairs also more or less reddish. . . . . . . . . . . . . . . 19.

Legs entirely black, sometimes hind tibiæ with dark castaneous tinge. . . . . . . . . . . . . . . . . . 27.

19. Wings of male with two large black marks; vertex little excavated and heavily deep golden pollinose; mesonotum deep golden pollinose, the four corners shining; mystax golden; abdomen with yellow lateral tufts; segments 2-5 with broadly interrupted posterior fasciæ. Wings of female infuscated over apical part and over end of anal cell; color of pile and pollen less deep. Anterior crossvein near middle of discal cell. (N. H., Minn., N. M., Col., Wyo., Id., Or., Wash.) . . . . . . bimacula Walk. Wings not bimaculate; vertex more evidently excavated; 20 .

20. Abodmen of male with a large tergal patch of dense fulvous tomentum; hypopleural hairs white.(Ont.) vulneratus,n. sp. Abdomen without such mark of fulvous tomentum. . 21 .

21. Male front tarsi with recumbent silvery pile, last two joints of middle tarsi of male with disk of black hairs; gray pruinose marks of abdomen very small and located at hind angles of the segments. (If male front tarsi silvery but middle tarsi without disk, see tacomœ.) : . . . . 22.

Front tarsi without silvery recumbent hairs and middle tarsi without black disk.

22. Silvery hairs of male front tarsi parted; black disk of middle tarsi confined to last two joints. . . . . . . . . . . . 23.

Silvery hairs of front tarsi not parted, beginning on second joint; short black hairs on third joint of middle tarsi beginning the disk; pulvilli dark brown. . . . . . . . 24 .

23. First two segments of abdomen with white pile on sides, in male contrasting with black pile on remainder; front metatarsi of male not silvery above, but densely beset on both sides below with black bristles; pulvilli whitish. (Cal., N. M., Wyo., Col.) . . . . . . callipedilus Lw. Abdomen with black pile over all; front metatarsi of male silvery above and not spinose beneath; pulvilli brown. (Cal.) . . . . . . . . cymballista O. S. 
24. Scutellum and most of thorax shining; pile of abdomen yellow and black. (B. C. ,Alta., Wash.) (Can. Ent. 1922, 277) . . . . . . . . . . . . . willistoni Curran.

Base of scutellum and much of thorax brown pollinose; pile of abdomen yellow. (N. M., Utah, Id., Col., Neb.)

25. Gray pruinose marks of abdomen confined to hind angles of segments; pile of face deep golden; pile of hypopleuræ yellow, of abdomen yellow except at end; tibiæ abruptly black on apical half. (N. S., Queb., Ont., N. H., Mass., N. Y., Ct., N. J., N. C., Fla., Ill.) (If legs are entirely dark chestnut, see alleni) . . . . falto Walk.

Gray pruinose marks following hind margins of abdominal segments; pile of face whitish, black on sides; hind tibiæ not black apically. . . . . . . . . . . . . . . . . . . 26 .

26. Hairs of hypopleuræ black; abdominal fasciæ narrowly interrupted, sometimes entire in female; pile of abdomen mainly black. (Col., N. M., Cal., Id., Wash., B. C.) montanus Lw.

Hairs of hypopleuræ white; abdominal fasciæ entire; pile of abdomen white Male unknown. (Cal., N. M., Or.) . . . . . . . . . . . . . . leucozona Lw.

27. Middle segments of abdomen with complete fasciæ; male front tarsi elongate, tarsal hairs chiefly white, long on upper side of basal three joints of hind pair, tarsal hairs of female chiefly black; hypopleural hairs black; halteres blackish brown; extensor hairs of hind tibiæ white. (Cal., Wash., B. C.) (If hind tibiæ are dark chestnut color, see montanus) . . . . . . . . . longimanus $\mathrm{Lw}$.

Fasciæ of abdomen interrupted, sometimes reduced to lateral spots; crossveins, etc., usually clouded. . . . . 28.

28. Fasciæ broader than long, following the hind margins; front tarsi of male slender . . . . . . . . . . . . . 29.

Fasciæ confined to hind angles of segments. . . . . 30 .

29. Front tibiæ and tarsi of male with not dense white pilef which does not conceal the ground-color; hind tarsi 0 , 
male darker than others; claws broadly yellowish; humeri subshining. (Mont.) . . . . . . . . . rufotarsus Back. Front tibiæ and tarsi of male with appressed silvery pile concealing the ground-color at least of tarsus; middle tarsi darkest; claws black the base reddish; humeri and adjacent region of thorax heavily silvery-white pruinose. (Wash.) . . . . . . . . . . . tacoma n. sp.

30. Front tarsi of male with single row of silvery pile from very base; last two joints of middle tarsi with the flat disk of black pile longer than broad; pile of abdomen yellowish white at base, black apically. (Wash., Or.) (If front metatarsi of male are not silvery, see Willistoni)

Front and middle tarsi of propes Will

31. Scutellum with long black pile; mystax and hypopleuræ pile black; pleuræ shining above; notal pattern including mark like a tuning-fork. (N. H., N. Y., N. C.) lyratus O .S. Scutellum with short white pile; mystax partly white, hypopleural pile white; pleuræ densely white pruinose. (N. H., N. C.) . . . . . . . . . . . . . alleni Back.

32. Abdomen with pollinose markings at least of segments 24 extending from side to side. . . . . . . . . . . . . 33 . Abdominal fasciæ interrupted, sometimes subinterrupted, that of first segment sometimes entire. . . . . . . . . 39 .

33. Greater part of middle segments of abdomen covered with gray pollen and the front angles polished; hypopleural pile white. . . . . . . . . . . . . . . . . . . . 34 . Greater part of abdominal segments shining, or if largely pollinose the pollen extending along the sides so that the front angles are not polished. . . . . . . . . . . . 36 .

34. Pollen denuded in circular spot in middle of each tergite; tibiæ with many white bristles, male with brushes of white hair on front side of middle tibiæ below knee and on front side of middle metatarsi. (Wash.) . . . ablautoides, n. sp. Middle of tergites pollinose, or if shining not forming a central round spot; white hairs of legs evenly distributed. 
35. Hypopleural pile black; hairs of hypopygium yellowish white; mystax white; abdomen of both sexes gray except front angles of segments; tibial bristles white except those at tips and on front side of first pair. (Cal.) . . rattus O.S. Hypopleural pile white; hypopygial hairs black above; mystax white and black; anterior half of male abdominal segments shining; tibial bristles black, a few pale ones on extensor side of hind tibiæ of female. (Wash.)

coesius, $\mathrm{n}, \mathrm{sp}$.

36. Face convex below but not gibbous, facial pile dense and white; tibiæ reddish at base; male abdomen broad, with sides and posterior margins pollinose, female abdomen narrow, anterior margins of segments $2-4$ sometimes also pollinose. (Or., Wash.) (Proc. Cal. Acad. Sc. 1919, 230) . . . . . . . . . . . anomalus Cole.

Face more gibbous, its pile largely or wholly black. . . 37 .

37. Legs largely brownish red; geminate stripe of thorax distinct and complete; pollen of abdomen confined to posterior and side margins of segments; style one-third the third antennal joint; scutellum without bristles; face and front brownish gray. (Ks., Col., N. M.) . . profusus O.S. Legs black; scutellum with black bristles. (If scutellum with only marginal pile, see nugator female if facial hairs all black, or coesius male if facial hairs white.) . . 38 .

38. Abdominal fasciæ extending along posterior edge of segments; stripes of thorax very distinct. (Cal.) evidens O. S. Abdominal fasciæ extending along anterior margin of segments 2-6 but not reaching sides, posterior angles with spots of white pollen; stripes of thorax indistinct; style one-tenth the third antennal joint. (Cal.) cerussatus O.S.

39. Legs in part reddish; mystax black. . . . . . . . . . 40. Legs black, rarely the knees alone brownish. . . . . . 41 .

40. Hypopleural pile whitish; mystax rather sparse; wings hyaline; mesonotum largely gray. (Ariz.) . tibialis . Coq. Hypopleural pile black; mystax dense; wings brownish apically, crossveins clouded; mesonotum largely brown. (Or.) . . . . . . . . . dubius Will. 
41. Bases and hind angles of abdominal segments pruinose, sides of first segment pruinose; anterior crossvein beyond middle of discal cell; mystax and hypopleural hairs mainly black; thorax largely gray, marks diffuse, pleura bear of pile, scutellar margin with strong bristles.

(Cal.) . . . . . . . . . . . . . . . nigricolor Coq.

No fasciæ at base of segments; scutellum more or less pilose; thorax darker.

42. Hypopleural pile wholly or in large part white. . . . . 43. Hypopleural pile wholly black. . . . . . . . . . . . 47.

43. Pleuræ with polished spot beneath wings; tibial bristles white; first abdominal segment with entire fascia. (N. S., Mass., N. Y. Md. Va.) . . . . . . lutatius Walk. Pleuræ wholly pollinose and with some fine pile; tibial bristles mainly or entirely black; fascia of first segment of abdomen interrupted. . . . . . . . . . . . . . . 44 .

44. Scutellar pile pale yellow, wings hyaline; facial pile mixed white and black. (Or.) (Proc. Cal. Acad. Sc. 1921, 255) thompsoni Cole

Scutellar pile black.

45. Scutellar pile abundant; wings dark, especially in male; facial pile white in male, black in female. (Or.) (Proc. Cal. Acad. Sc. 1919, 233) . . . . . . . . infuscatus Cole. Scutellar pile sparse and marginal; facial pile black. . . 46 .

46. Tarsal claws yellowish with black tip; wings hyaline; median stripes as distinct as the blackish lateral spot. (Cal., Or., Wash., Id.) . . . . . . . . nugator O. S.

Tarsal claws reddish at base, otherwise black; wings brownish hyaline; median geminate stripe of mesonotum abbreviated posteriorly and less distinct than the rich dark brown lateral spot. (Cal. Or.) . . . . rejectus O. S.

47. Front and face broad, cinereous; notal marks often feeble. (Cal.; Or., Wash.) . . . . . . . . . . . . sudator O.S.

Front and face relatively narrow, brownish; notal stripes coalescing, dark brown. (Cal., Ariz., N. M., Id.) 


\section{Cyrtopogon ablautoides, new species}

Male.-Length $11 \mathrm{~mm}$. Head cinereous pollinose, frontal hairs whitish, becoming black at orbits, hair of center of face dense and white with slight yellowish tinge, of sides and beneath black, hairs of occiput abundant, silvery, nearly white, antennæ slender, the style one-fourth as long as third joint, its basal segment scarcely visible. Thorax dusted with yellowish-gray pollen, the geminate stripe interrupted one-third the distance in front of scutellum, lateral stripes nearly obsolete, slightly darkened in front of suture and a weaker indication behind, three strong lateral presutural bristles, four intraalar, postalar callosities with four black bristles; hairs of notum white in front, a few blackish hairs intermixed behind, scutellum flat, brownish-gray pollinose, disc with erect white pile, margin with white pile, about six black setæ, pleuræ gray pollinose with yellowish tinge on mesopleura which also bears long white pile, trichostical hairs yellowish-white. Abdomen with shining or subshining anterior margins to the segments the posterior margins white pruinose, a central subshining black spot on each of segments two, three and four, sides of segments two, three and four subshining except posteriorly, the first three segments bearing dense lateral tufts of whitish yellow hair, hair of remaining segments sparse short and white, hypopygium small and subshining black. Legs dusted, femora with whitish pile, front tibiæ bristly, the bristles of extensor face stout and black, of posterior face strong and yellow, of interior face fine and setiform, flexor surface golden pubescent; middle tibiæ with dense cluster of white pile at two-fifths its length on anterior face, bristles mainly whitish, similar tuft of white pile on front face of middle metatarsus; bristles of hind tibiæ whitish and black mixed, claws black, pulvilli alutaceous. Halteres with pale yellow knob, calypteres yellow; wings hyaline, veins narrow and black, anterior crossvein at two-fifths length of discal cell, anal cell closed or narrowly opened at margin.

Female.-Apical segments of abdomen shining black.

Types.-Mabton, Washington, May 3, 1911 (Melander). Paratypes from Lind, Wash. May and June (F. W. Carlson), 
Columbia River near Trinidad, Washington, May 1, 1919 and Wenatchee, Washington, April 12, (Melander). Four males and six females. The species presents a curious superficial resemblance to Ablatus mimus $\mathrm{O}$. S. with which it is associated in the sandy desert region.

Cyrtopogon caesius, new species

Male.-Length $9 \mathrm{~mm}$. Related to C. rattus O. S. Head heavily whitish pruinose, vertical hairs white and black mixed, facial hairs similar but longer, the black hairs predominating below, occipital pile abundant, white and very fine, third antennal joint long and slender, the arista not very distinct, quite as thick as end of third joint and in length about one-fourth the latter, its basal joint undeveloped. Thorax heavily pollinose, its pile rather short sparse and black, three black lateral bristles and a cluster of about three postalar, four intraalar bristles, median geminate stripe black, lateral stripe interrupted at the suture so as to form a broad presutural blackish round spot and an indefinite broad postsutural stripe, front margin and humeri grayish-white; scutellum flat, white pruinose, its margin with black setiform hairs and white pile; pleuræ uniformly white pollinose, pectus with fine white pile, trichostical hairs dense and white. First abdominal segment entirely white pruinose, second and third segments with narrow white band on front margin and broad white band on hind margin, the intervening space shining black, remaining segments shining black, the hind margin broadly white pruinose, the white bands do not encroach forward on the sides of the tergites; hypopygium scarcely widening at termination of the abdomen, lateral valves cupuliform; hairs of abdomen long tufted and white at side margins of basal three segments, largely short and black on remaining segments, under side of hypopygium with yellow hairs, tuft of grayish hairs at apex of venter. Legs entirely black, femora and posterior tibiæ white pilose, front tibiæ with black pile on front face, dense yellow pubescence on inner face and loose comb of black setiform hairs on both outer and flexor surfaces and another comb of black bristles on forward face, setiform 
hairs of middle tibiæ long and black, of hind tibiæ almost bristlelike, forming rows on extensor and anterior faces, claws black, pulvilli alutaceous. Halteres of each specimen with rosy knob, calypteres yellowish; wings hyaline, veins black, anterior crossvein at one-third the length of the discal cell, anal cell open as widely as the length of anterior crossvein or less.

Female.-White hairs predominating on vertex and upper part of face, marginal bristles of scutellum stronger, white pruinosity of abdomen more extended, the second third and fourth segments with shining narrow base, expanding as an anterior quadrate shining spot at side margin, remainder of segment white pruinose, posterior segments similarly colored except that the lateral expanse of shining area is more triangular, seventh and eight segments polished black. Tibial bristles stronger.

Types.-South slope of Mount Adams, Washington, July 24, 1921. (Melander). Two males, seven females, taken at an elevation of 4000 feet.

\section{Crytopogon glarealis, new species}

Male.-Length $14 \mathrm{~mm}$. Head with golden tomentum, upper hairs rather sparse and black, mystax black, the lowermost hairs mixed with golden, beard white, third antennal joint reddish-yellow, style black and one-fifth the length of the third joint. Mesonotum with fulvous pollen, middle stripes very indistinct, humeri and postalar callosities shining, pollen denuded on posterior half of thorax except a quadrate spot next to scutellum, scutellum convex and shining except for a touch of pollen at middle of base, notal hairs sparse and black, scutellar hairs mostly black, not dense, no marginal bristles; pleuræ uniformly dusted with brown-gray pollen, meso and sternopleuræ pilose, hypopleural hairs black, the lowermost brown. Abdomen mostly polished, segments two to four with yellowish posterior fasciæ, the tomentum extending along middle of segments two, three, four and anterior two-thirds of segment five as a dorsal vitta, pile of abdomen entirely black, short, tufted on sides of second segment; base of hypopygium with stubby black 
setæ, lateral valves with two terminal prongs. Coxæ pollinose, the front pair with white hairs; femora shining black, flexor hairs yellowish, dorsal hairs mainly black and inconspicuous; tibiæ reddish brown, hairs black except towards apex of front pair where they are whitish, bristles strong, abundant and black; anterior tarsi yellow, hind tarsi reddish, the front pair with brush of yellowish-white hairs covering outside face, inside face with conspicuous black bristles, a few black bristles on flexor face of metatarsus, bristles of posterior tarsi heavy, numerous and black; basal half of claws yellow, apical half black, pulvilli white. Knob of halteres pale yellow. Wings sub-hyaline,a slight brownish tinge at furcations, anterior crossvein at basal third of the discal cell which is nearly four times as long as broad.

Female.-Prescutellar dusted area more extensive, dorsal stripe wanting on abdomen, pile of abdomen yellowish, longest on sides of basal segments. All tarsi reddish, almost no whitish hair on front tibiæ and tarsi, bristles of front tarsi stronger than in male.

Types.-Wolf Fork of Touchet River in the Blue Mountains of southeastern Washington, Three specimens, July 12-20, 1922. (V. Argo).

Cyrtopogon punctipennis, new species.

Male.-Length $7.5 \mathrm{~mm}$. Closely resembling C. nebulo O.S. but without fimbriate costa. Vertex and face black with slight violaceous tinge, thinly overlaid with white pollen, more distinct along facial boundaries, pile of front fine dense and black, of face longer and more abundant, the individual hairs tipped with whitish, third antennal joint tapering, the arista nearly equal in length, slender with first segment distinct, occiput with light bluish tinge, orbits white pollinose, hairs very fine abundant and hairy. Thorax bluish-black in ground-color, median stripe of white pollen extending from neck to scutellum, dorso-central stripes of white pollen broadening behind, lateral and posterior margins largely blue pollinose, when viewed from in front the notum shows four silvery spots, the posterior ones on the suture, 
the anterior ones half way to the front margin; pile abundant and black, three fine lateral bristles; scutellum convex, shining blue-black, its silky pile long and white, no bristles, pleuræ uniformly and lightly cinereous dusted, ground-color blue-black, pile of pectus white, trichostichal hairs white and black mixed. Abdomen shining blue-black, extreme posterior corners of segments white pruinose, pile rather sparse short and pale, becoming darker in back, hypopygium very small, sunken, venter with bluish-gray pile, the hairs very dense on apical third. Legs entirely blue-black, front coxæ with abundant whitish pile, hairs of femora pale at base, front tibiæ with a row of very long bluish hairs on posterior edge, these hairs continuing on first three tarsal joints, hind tibiæ brown pubescent within, claws black, pulvilli brownish. Halteres black, calypteres alutaceous; wings lightly infumated, paler along portions of the first three veins, marked with distinct blackish spots at the bases of submarginal cells and of first and second posterior cells, the last two spots sometimes thickened and extending basally to the crossveins, costa blackish from end of first vein to tip of wing.

Female.-Hairs somewhat shorter, notum more heavily pollinose so as to appear brownish in general color, median bisected stripe almost black; scutellum brownish pollinose, with about eight marginal setiform hairs; frontlegs marked with a prominent comb of hairs.

Types.-Moscow Mountain, Idaho, various dates from May to October (Melander); Pullman Washington; Goodnoe Hills, Washington (A. C. Burrill).

Cyrtopogon semitarius, new species.

Male.-Length $15 \mathrm{~mm}$. Resembling dasyllis. Upper part of head black with abundant black hair, facial hair mainly white, along oral margin black, beard fine and white, palpal hairs black, antennæ black, style deformed, as wide as long, blunt, apically with a concavity in which the minute terminal joint is inserted. Thorax largely shining, a very narrow indistinct median line of grayish-brown dust, a mark of similar dust bear- 
ing the supra-alar bristles and a less extended similar mark above humeri, posterior half of mesonotum and scutellum shining black; hairs of thorax abundant, erect and black, of scutellum dense and black, no bristles; pleuræ with very faint touch of dust, mostly shining, black pile on meso, sterno, and hypopleuræ, the later dense and long. Basal three segments of abdomen uniformly and densly clothed with long pale yellow hair, apical half of abdomen shining and provided with dense short black pile, tip of hypopygium with a few yellow hairs; pile of venter entirely black. Coxæ and femora shining black, posterior tibiæ dark castaneous, tarsi reddish; pile of front face of front coxæ white, of exterior face of hind coxæ yellowish white; pile of femora mostly black, that of posterior face of front femora white, femoral bristles black; pile of extensor face of anterior tibiæ abundant and white, of entire hind tibiæ black, inner face of front tibiæ with fulvous pubescence, middle tibiæ with lateral black bristles, hind tibiæ with rows of black bristles, particularly on extensor, anterior and apical half of flexor faces; basal half of claws reddish, apical half black. Stem of halteres black, knob pale yellow. Wings hyaline, veins black, anterior crossvein at basal fifth of discal cell, the discal cell nearly five times as long as wide.

Holotype.-Alta Vista, Mt. Rainier, Wash., July 29, 1922 (Melander).

The specimen was taken from its vantage position on one of the ghost trees on the Alta Vista ridge. The structure of its style is unique but is probably not the result of a deformity, since the two antennæ are alike.

Cyrtopogon tacomae, new species.

Closely related to C. rufotarsus Back. Ground-color entirely black, thorax beautifully marked with silvery white pattern, extensor face of front tibiæ and tarsi of male densely covered with appressed silvery-white hairs, middle legs normal, anterior and extensor faces of hind tibiæ of male with white hairs, front and hind tarsi sometimes fuscous. 
Male.--Length $10 \mathrm{~mm}$. Antennæ black, third joint broadening underneath, thickest at two-thirds its length, style onefourth as long as the third joint; front and face heavily silverygray, occiput subshining, more whitish at orbits, facial gibbosity nearly hemispherical, its central hairs long and silverywhite, mystax entirely black, beard largely white, frontal hairs long, delicate, not abundant, black. Thorax viewed from above presenting the following pattern in dark brown pollen: a bisected median stripe contiguous with a presutural round spot, and the entire postsutural area except postalar callosities and a narrow triangle in front of the convex shining scutellum, - this brown picture changing to shining black when viewed from behind; viewed from in front the anterior portion of the mesonotum is silvery-white pruinose, but from above a posthumeral area appears subshining black; all hairs of thorax black; pleuræ subshining lightly coated with brownish dust, but whitish pruinose above front coxæ, on upper sternopleura and narrowly along posterior part of mesopleura. Abdomen polished black with slight violaceous tinge, lightly dusted on apical segments, hypopygium polished, interrupted silvery-white fasciæ along posterior part of segments 2-6, narrowly leaving the hind margin on segments 2,3 but attaining the hind edge on segments 4-6, the marks of the sixth segment less distinct, all hairs of abdomen black, those at sides of first three segments long and almost tufted. The silvery hairs of front tarsi cover the ground-color; the middle tarsi are always black, the front and hind ones sometimes are brown but usually are quite black; inner face of front tibiæ and metatarsi densely coated with glistening fulvous depressed short pubescence, similar fulvous pubescence extends along posterior face of hind tibiæ; pulvilli and basal third of claws brown. Halteres with yellowish knob; wings with brownish tinge and with brownish markings occupying the root, auxiliary cell, furcation of veins, crossveins, and forming an oblique band along first section of third vein, the anterior crossvein at basal fifth of discal cell.

Female.-Larger by one or two millimeters. Front largly lightly dusted with brown, face and central hairs less pure white. 
Tarsi usually black, sometimes reddish, lacking the silvery ornamentation of the male. Notal picture more definite, humeri appearing subshining only when viewed from above, posthumeral spot of male appearing silvery-white, a quadrate prescutellar area emitting two anterior extensions pruinose, base of scutellum lightly pruinose; whitish pruinosity of pleuræ more extended, the entire mesopleura except central brown spot pruinose,pile of sides of prothorax and of sternopleura white. Hairs at base of abdomen pale yellow and less conspicuous, sides of first segment also with pruinosity, sixth and following segments entirely shining black. Wing markings less distinct, auxiliary cells hyaline.

Types.-Mount Rainier, Washington, various places in the natural parks visited at about 5000-6000 feet elevation. In all over ninety specimens were secured, including four collected by Dr. Aldrich. The flies were observed alighting on stones in the sunny pathways and were encountered in Paradise Park, Van Trump Park, and Indian Henry Hunting Ground, on Alta Vista, Mt. Ararat, and Crystal Mountain.

A grant from the Elizabeth Thomspon Science fund for the purpose of studying the alpine insects of Mount Rainier made possible the securing of much of the type material. Paratypes have been deposited in the National Museum, the Canadian National Museum, the Museum of Comparative Zoology of Harvard and the Philadelphia Academy of Science.

Cyrtopogon vulneratus, new species.

Male.-Length $10 \mathrm{~mm}$. Readily distinct in having a large spot of heavy fulvous tomentum beginning at middle of second segment of abdomen and reaching to hind margin of fifth. Front and face thickly clothed with pale golden tomentum, a denuded spot between antennæ and front ocellus, facial hairs yellow, mystax black, frontal hairs sparse, fine and black; upper occiput rather lightly dusted with dull yellow pollen, brighter along orbits, a denuded spot underneath each ocellus, hairs sparse and black, lower occiput with brighter yellow dust, beard silky 
delicate and white; antennæ black, basal joints equal, hairs few and black, third joint slightly longer than basal joints together, style acuminate, one-eigth the length of the third joint. Pronotum shining black, a median inverted trianglar mark and a subhumeral spot of golden pollen, sides with tuft of white pile; mesonotum tomentose except postalar callosities and adjacent area, median geminate stripe light brown, interrupted a short distance behind suture, the usual broad lateral stripe consisting of a vaguely rounded mark on each side of suture, humeri golden, front part of mesonotum golden-gray, rear middle part cinereous; notal hairs short, sparse and black, lateral bristles black; scutellum convex, shining black, a touch of yellow pollen at base, no discal hairs, marginal hairs sparse and black; pleuræ lightly cinereous, more golden above, pteropleura shining, trichostichal hairs white. Abdomen slender, shining, sides of first segment with tufted white pile, of second segment with looser white hairs, third and fourth segment with short fulvous hairs; fifth, sixth and seventh segments and hypopygium with black hairs, posterior margins of second to fifth segments laterally golden tomentose, hypopygium globose, wider than termination of abdomen; venter black, hairs yellow. Femora black, tibiæ and tarsi reddish except apex, hairs largely whitish, bristles black, two strong yellow bristles near middle of anterior face of hind femora, inner face of front and hind tibiæ with close deep golden pubescence, claws black with brown base. Halteres and calypteres yellow, wings broad and hyaline, veins piceous, yellowish at base, a very faint cloud over crossveins, anterior crossvein at one-fifth length of discal cell, anal cell briefly open.

Holotype--Coniston, Ontario, 27, July (H. S. Parish). 

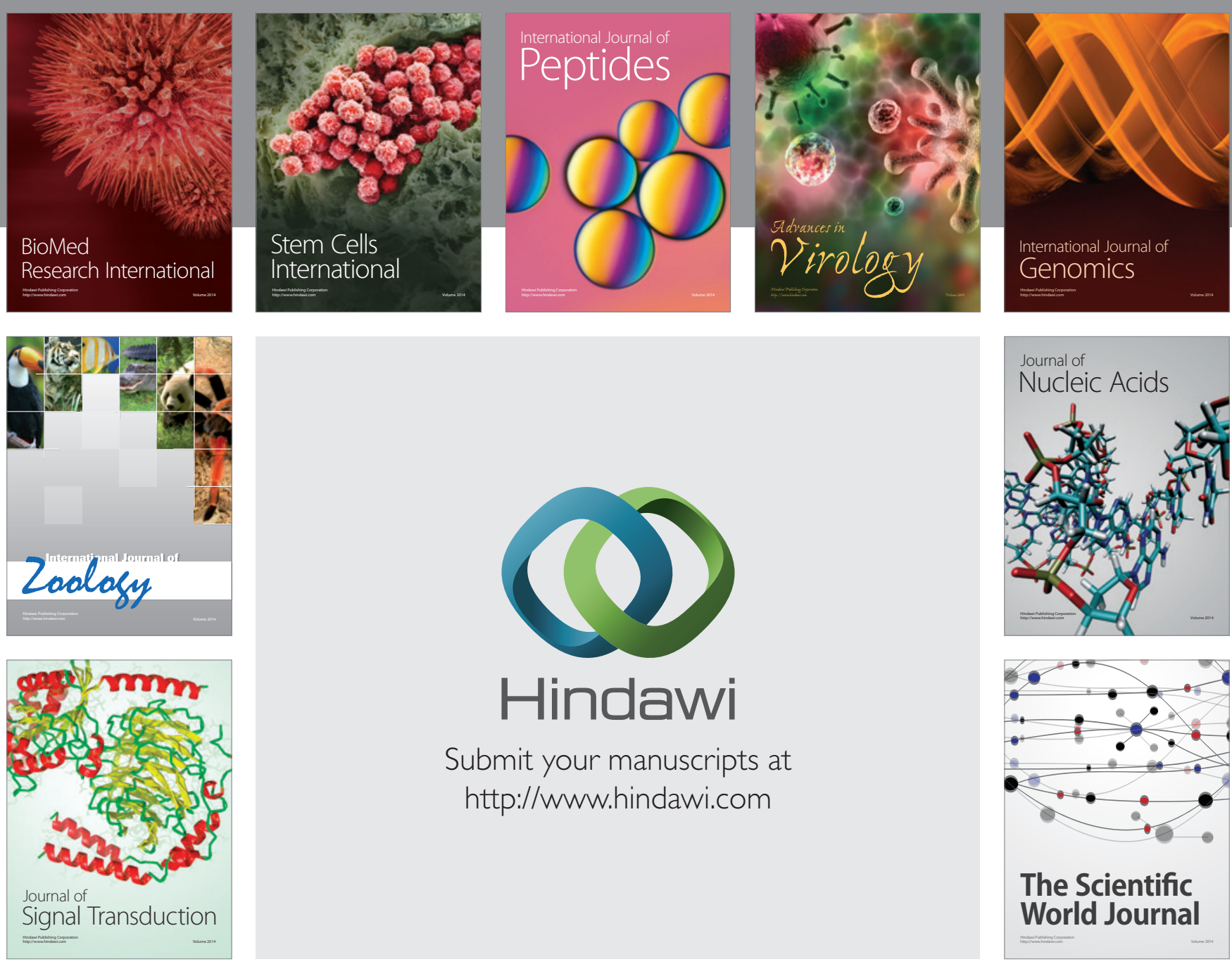

Submit your manuscripts at

http://www.hindawi.com
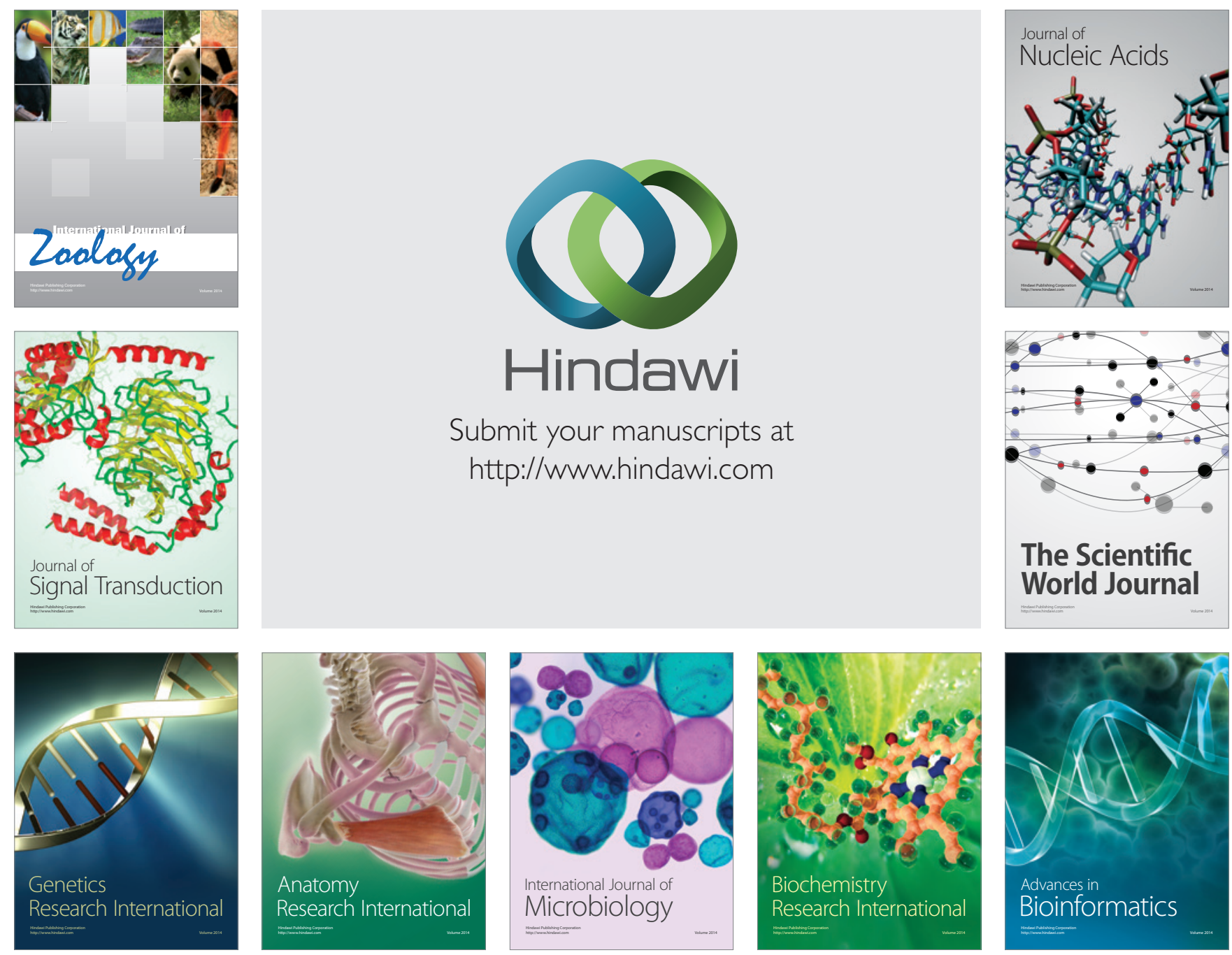

The Scientific World Journal
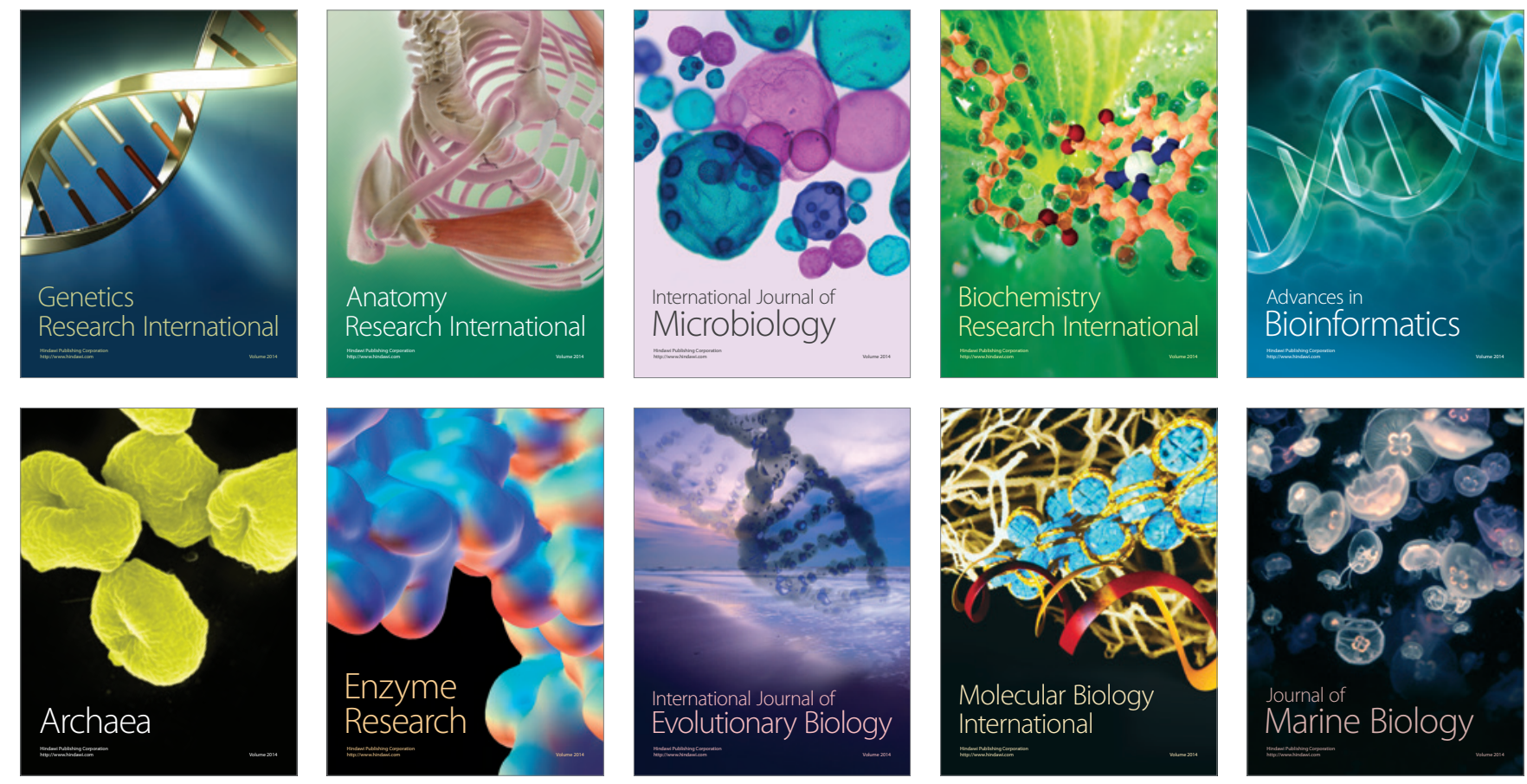